\title{
THE IMPLEMENTATION OF SHARIA MARKETING TO INCREASE CUSTOMER SATISFACTION AT MUAMALAT BANK OF BANTUL BRANCH OFFICE
}

\author{
Istiqomah \\ STEBI Al Muhsin Yogyakarta \\ Email: ieyzthieynazarama@gmail.com \\ Richa Angkita Mulyawisdawati \\ STEBI Al Muhsin Yogyakarta \\ Email: mulyawisdawati205@gmail.com \\ Meriyati \\ STEBIS IGM Palembang \\ Email: meri@ stebisigm.ac.id
}

\begin{abstract}
The development of Syariah banking in Indonesia was marked by the establishment of Syariah Banking in all parts of the region. However, it cannot be denied that many people think that there is no difference between Islamic Banking and Conventional ones. This is a challenge for Syariah Banks in Indonesia, including Bank Muamalat Indonesia, namely the first pure Syariah Bank which was established in 1991 in retaining customers through business undertaken an effort to provide customer satisfaction by products and services offered. This study aims to identify how the implementation of Syariah Marketing Characteristics and principles of the Muamalat Bank of Bantul Branch Office. This Research is a descriptive-analytic study using a qualitative approach. The data was obtained through an interview process with the Marketing Manager and direct observation of the research object. The results showed that both the characteristics and principles of Syariah Marketing had been implemented as a whole by the Branch Office of the Muamalat Bank of Bantul Branch Office in all aspects of marketing performance.
\end{abstract}

Keywords: Syari'ah Marketing, Satisfaction, Customer, Bank Muamalat Indonesia

\begin{abstract}
Abstrak
Perkembangan perbankan syariah di Indonesia ditandai dengan berdirinya Perbankan Syariah di seluruh wilayah. Namun tidak dapat dipungkiri, banyak orang yang menganggap tidak ada perbedaan antara Perbankan Syariah dan Perbankan Konvensional. Hal tersebut menjadi tantangan tersendiri bagi Bank Syariah di Indonesia termasuk Bank Muamalat Indonesia yaitu Bank Syariah murni pertama yang didirikan pada tahun 1991 dalam mempertahankan nasabah melalui usaha yang dilakukan dalam upaya memberikan kepuasan nasabah melalui produk dan layanan yang ditawarkan. Penelitian ini bertujuan untuk mengetahui bagaimana Penerapan Karakteristik dan Prinsip Pemasaran Syariah Bank Muamalat Kantor Cabang Bantul. Penelitian ini merupakan penelitian deskriptif analitik dengan menggunakan pendekatan kualitatif. Data
\end{abstract}


180 | Istiqomah, Richa Angkita Mulyawisdawati, Meriyati, THE IMPLEMENTATION OF SHARIA......

diperoleh melalui proses wawancara dengan Manajer Pemasaran dan observasi langsung terhadap objek penelitian. Hasil penelitian menunjukkan bahwa baik karakteristik maupun prinsip Pemasaran Syariah telah diterapkan secara utuh oleh Kantor Cabang Bank Muamalat Kantor Cabang Bantul dalam semua aspek kinerja pemasaran.

Kata Kunci : Pemasaran Syari'ah, Kepuasan, Nasabah, Bank Muamalat Indonesia

\section{Introduction}

Sharia banking in Indonesia is rapidly developed. Sharia banking also can demonstrate its identity as a milestone in creating a system of financial stability. It proved that in the event of the monetary crisis of 1998, Syari'ah Bank was able to thrive and compete with the conventional Bank (Aisjah \& Hadianto, 2013). The monetary crisis that occurred in the year 1998 ago has submerged the conventional banking sector so that not least a conventional Bank is liquidated because of the failure of the interest system. But the banking operating with the sharia system can survive and still exist. During the global financial crisis that struck the world at the end of 2008, the sharia financial institutions again demonstrated its ability to defend its existence from crisis exposure. Sharia Financial institutions still remain stable and provide security, comfort, and benefit for some of them are its shareholders, securities holders, financing clients, and their funds depository customers (Nofinawati, 2016).

Nofinawati (2016) also declared that it is evidenced by the success of Bank Muamalat Indonesia capable of passing the monetary crisis in 1998 by demonstrating the existence of its performance that is increasing without receiving any percent from the government. While in the global economic crisis of 2008, Bank Muamalat Indonesia was even able to obtain a profit of Rp 300 billion more.

As time went on sharia banking expansion began to yield results. It is seen from Sharia Bank has shared about $6.01 \%$ to the banking industry as of October 2019 based on the Financial Services Authority (OJK) data or reached Rp 513 trillion. When detailed, the achievement was the highest number in history and increased from the beginning of 2019 to September 2019 by $5.94 \%$ (OJK, 2019). This is evident from the increasing growth of sharia banking assets, namely the Bank of Sharia (BUS) and Sharia business units (UUS), amounting to $10.15 \%$ per October 2019 , year on year to 
Rp 499.98 trillion. The realization of bank Syari'ah assets was also driven by financing growth of $10.52 \%$ year on year to Rp 345.28 trillion- and third-party funds (DPK) which rose to RP 402.36 trillion (https://keuangan.kontan.co.id/news, 2020).

The achievement of the results is certainly supported by a series of Syari'ah Bank business marketing products and services to prospective customers. Following its system and operations, sharia banking should use Islamic guidelines and principles including in implementing its marketing management.

Syariah Marketing is a strategic business discipline that directs the process of creating, bidding, and changing the value of an initiator to its stakeholders, in the entirety of the process by the 'Aqad and the principles of rulings (business) in Islam (Mu'allim, 2003). In Sharia marketing, the whole process should not be any contrary to Islamic principles. During this business process can be guaranteed, or no deviation to the sharia principle, so any transactions in marketing can be allowed.

Emphasizing the character and nature of Prophet Muhammad in conducting business process, he showed how to do business in truth, honesty, and trust attitude while obtaining optimal profit. By sticking to the values found in the Qur'an and AlHadith, the Prophet Muhammad conducts business professionally. As for some traits that make prophet Muhammad succeed in his business, among others: (1) Honest or True, (2) trust or trustworthy, (3) Fathonah or intelligent and prudent, (3) Tabligh or argumentative and communicative (Kertajaya et al., 2006). As the word of Allah SWT in the Qur'an sura al-Ahzab verse 21 as follows:

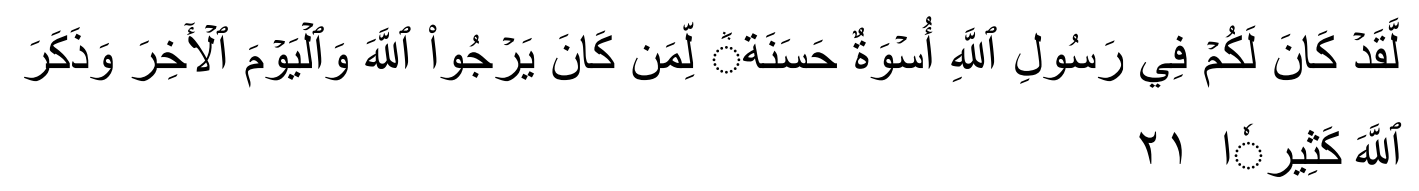

"Behold, the messenger of Allah is a good example for you (that is) for the people who Hope (mercy) God and the (coming) day of judgment and he calls God."

Marketing Strategy on the concept of Shari'ah marketing aims to win the mindshare, Syariah marketing tactic to win the market share, and sharia marketing in winning heart-Share. While Islam states that doing business is a halal job, at the same 
182 | Istiqomah, Richa Angkita Mulyawisdawati, Meriyati, THE IMPLEMENTATION OF SHARIA......

level it reminds explicitly that all businesses should not prevent them from always remembering God and the signs of his command (Kertajaya et al., 2006).

\section{Theoretical Framework}

\section{Overview of Implementation}

The implementation comes from the English language, the implementation which means implementation and implementation (Echols, et al., 1992) While Boediono Guntur Setiawan stated that the Implementation can also be interpreted as applying or expanding activities that adapt the interaction process between objectives and actions to achieve it and require an implementing network, effective bureaucracy (Boediono, 2001). According to Pius Abdillah implementation is to increase the activity, implementation, action, or the mechanism of a system, implementation is not merely an activity, but a planned activity and to achieve the objectives of activities (Abdillah, et al., 2005).

In the opinion of experts above, it can be concluded that implementation is a planned activity, not only an activity and done in earnest based on the reference of certain norms to achieve the objectives of the activity. Therefore, the implementation does not stand alone but is influenced by the next object of the curriculum. Based on the implementation of the above, researchers can interpret that implementation is an activity of implementation or implementation that has been planned based on certain rules to achieve the desired objectives within the company.

\section{Understanding of Shari'ah Marketing}

The word "Sharia"(al-Syari'ah) has existed in Arabic before the downfall of the Qur'an. The word that there are him also exists in the Torah and the Gospel in the Qur'an the word Shari'ah is mentioned only once in the word of Allah SWT as follows:

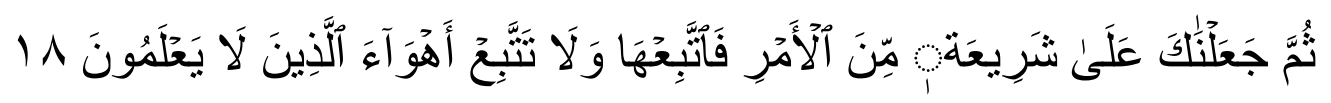

"Then we make you on a Sharia (rule) of affairs (religion), then follow the sharia and do not follow the lust of those who do not know." (QS Al-Jatsiyah: 18) 
Sharia comes from the word Syara'a al-Syai'a meaning "explain" or "explain something". Or, derived from the word syir'ah which means "a place used as a means to take water directly so that the person who took it does not need the help of other tools" (Kertajaya et al., 2006).

Shaykh Al-Qardhawi said, the scope of sharia according to the Islamic view is vast and comprehensive (Al-Syumul). In it contains the meaning of regulating all aspects of life, ranging from the aspect of worship (the relationship of man to his God), family aspects (such as marriage, divorce, living, wills, inheritance), business aspects (trade, industry, banking, insurance, debt-receivable, marketing, grants), Economic aspects (capital, zakat, Bait al-Mal, fa'i, Ghanimah), legal and judicial aspects, aspects of legislation to inter-State relations (Kertajaya et al., 2006).

Thus, Sharia marketing is a business discipline strategy that directs the process of creation, offering values from one initiator to its stakeholder which in the whole process corresponds to the agreement and the principles of the rulings in Islam (Kertajaya et al., 2006). This means that in Sharia marketing the whole process, either the process of creation, the bidding process, or the process of changing the value should not be contrary to the agreement and the principles of the rulings of Islam. So long as it can be guaranteed, and the deviation of Islamic principles does not occur in any transaction in marketing can be allowed.

The definition above is a provision in the Islamic business that exists in the rule of Fiqh which reads, "al-Muslimuuna 'Alaa Syuruuthikum illa sharthan harroma halaalan aw ahalla haraaman" (Muslims are related to the business agreements they make, except the prohibition of an agreement that is lawful or to justify the unclean). Besides, another fiqh rule says "al-ashlu fil muaamalah al ibaahah illaa ayyadullah daliilun ' Alaa Tahriimihaa" (basically all forms of rulings (business) can be done unless there is a prohibition evidence). 
184 | Istiqomah, Richa Angkita Mulyawisdawati, Meriyati, THE IMPLEMENTATION OF SHARIA......

\section{Sharia Marketing Characteristics}

\section{a) Theistic (Rabbaniyah)}

One characteristic of Sharia marketing that is not owned in conventional marketing is known during this time is its religious nature (Diniyyah). The soul of a Shariah marketer believes strongly that the Islamic laws of divinity are very fair so that a Shariah marketer will obey every marketing activity done.

Allah SWT says in Qur'an surah Al-Zalzalah verse 7-8:

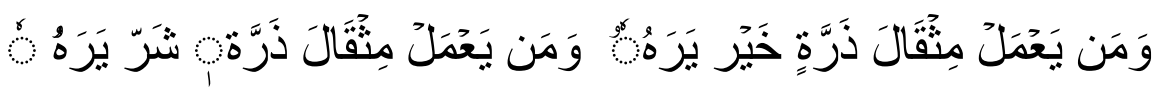

"Whosoever does a good of the Atomic seed even though, then he will see it and whosoever does an evil of an atom, even he shall see it also". (QS Al-Zalzalah: 7-8)

A shariah marketer will obey Sharia laws, in all its activism as a marketer. Starting from doing a marketing strategy, sifting through the market (Segmentation), then choose which market should be the focus (targeting), to establish the identity of the company that must always be embedded in the mind of the customer (positioning). With the existence of divine or religious nature in Sharia marketing, it is hoped that all sharia marketers can carry out their duties or activities as Islamic marketers following Islamic Shariah. Then, when he had to compose a marketing tactic, what became the uniqueness of his company than other companies (differentiation), as well as the marketing-Mix. Ethics of designing products, setting the price, determination, and in the promotion, always being animated by religious values. He must always put the Righteousness of God above all. And also, in the process of selling often a place of a thousand one kinds of opportunities to do fraud and fraud, the presence of religious values becomes very important.

Sharia marketers are confident of the most heart in that Allah SWT is always close and watching him when he is carrying out all sorts of business forms. He also believes that Allah SWT will ask him for the implementation of the sharia on the day when everyone is gathered to be shown (on the Day of judgement) (Kertajaya et al., 2006). 
ISLAMIC BANKING: Jurnal Pemikiran dan Pengembangan Perbankan Syariah, Volume 6 Nomor 2 Edisi Februari 2021

\section{b) Ethically (Akhlaqiyyah)}

Another specialty of a Shariah marketer is that, in addition to being theistic, it also emphasizes moral problems in all aspects of its activities. This Ethical nature is derived from the rabbinical (Rabaniyyah) nature. As such, Sharia marketing is a marketing concept that is address to moral problems (morality, ethics) regardless of any tribe, religion, or race. Because ethics is a universal value, taught by all religions especially Islam.

If someone is ethical in running his business wheel then he will find success. However, if doing business does not have ethics then he/she will experience failure. Rasulullah SAW once said to his people, "Verily I was sent to perfect the glorious morality." Therefore, this should be a guide for sharia marketers to always maintain morals and ethics in every behavior, speech, and decisions. To achieve this sacred purpose, Allah SWT instructs His apostles. His instructions include everything that is needed by man, whether creed, morality (moral, ethics), and sharia. Both do not undergo any changes at different times and places. Sharia is always changing according to the needs and the level of human civilization, which varies according to the individual apostles. It is expressed by the Prophet Muhammad in a hadith:

"The Prophets are not like his brethren. Their shariah is many, but his religion (creed) is one (i.e. administering God) " (narrated Al-Bukhari, Abu Dawood, and Ahmad).

The seriousness to always live net born inner is one way to achieve the degree of glory on the side of Allah SWT. In the Qur'an is spoken, ".... Indeed, Allah loves those who repent and love those who purify themselves "(QS. Al-Baqarah:(2) 222).

Islam is a religion that governs everything in the heavens and the earth, including ethical problems. Not only ethical in conducting daily activities, Islam also teaches ethics when on the market or in buying and selling. The assumption that the worst place in the market is caused by the easy deed and the fraudulent words of the business people in the market. Some Islamic ethics for business people both traders and marketers as follows; (1) behave well and sympathetic; (2) behave in 'Adl; (3) being serving and 
186 | Istiqomah, Richa Angkita Mulyawisdawati, Meriyati, THE IMPLEMENTATION OF SHARIA.......

humble; (4) keeping promises and not cheating; (5) honest and trustworthy; (6) to apply good managerial; (7) do not thought bad and to be unkind; (8) not swear when trading; (9) No bribes (Kertajaya et al., 2006).

\section{c) Realistic (Al-Waqi'iyyah)}

Realistically real means. Islam is revealed to interact with real-life object reality. Also, its teachings are designed in such a way that it is possible to be applied significantly in human life. Syariah Marketing is a flexible marketing concept, as well as the breadth and suppleness of Islamic principles. Syariah Marketing is a professional marketer with a clean, neat, and understated appearance, regardless of the model or style of dressing he wears. They work professionally and promote religious values, righteousness, moral aspects, and honesty in all its marketing activities. Sharia marketing must be familiar in the situation of associations in a very heterogeneous environment, with a variety of religions, tribes, and races.

Flexibility is given by Allah SWT so that the application of Sharia is always realistic and can follow the development (shaluhin likulli amaan wa makaan). The sense of the meaning of a realistic principle involves the ease of being done instead of utopia, solving problems, emphasizing simplicity, and positivity towards thought. The realistic richness of Islamic teachings also appears on the aspect of faith that believes something based on evidence, worship, non-imposing, spiritual, and material needs is prioritizing balanced between the world and the Hereafter, laws or rules compiled not contrary to defamation, as well as individuals and communities have the right and responsibility (Kertajaya et al., 2006).

\section{d) Humanistic (Al-Insaniyyah)}

The specialty of Islamic marketing is its universal humanistic nature. The humanistic (Al-Insaniyyah) sense is that the sharia was created for mankind to be lifted, the nature of his humanitarian awakens and preserved, and the properties of its animal can be buried with the guidance of sharia. By having a humanistic value, it becomes a 
controlled and balanced non-human being who is greedy of all means to achieve maximum profit.

This character is also an Islamic character that means that Islam Allah SWT makes life guidelines for human beings by the nature and elements of humanity. Islam is not a religion that is prescribed for angels and Jinn so that human beings are not power or incapable to do so, Islam is very caring for aspects of "human beings" with the various advantages and disadvantages contained in the human self. So, from here Islam is not only a religion that seems to be devoted to its religious characters only. But in Islam all adherents can do Islam to the fullest and perfect.

The specialty of Islamic marketing is the universal humanistic nature. Islam with its legal device constitutes human beings as a noble person, wakefulness of humanity, and kept away from the nature of greed because of the sharia that set it. The Qur'an as a guideline is universal and the Prophet Muhammad SAW as the messenger of Allah SWT who carries sharia as a universal apostle as well. This humanist value leads marketers to maintain fraternities, slings to know, help, assist, and prejudiced fellow business people to create harmony between businesses.

Therefore, the Prophet Muhammad SAW order to establish Ukhuwah. The principle of this brotherhood is used as the main principle. It would be wonderful if the Prophet's Prayer, "... I testify that all thy servants are brothers " characterize and the character of all men in all interactions in business, in competing healthily, in partnering, and in rebuilding our nation who already torn mutually suspect one another, is a provocation of the interest of the group so that not infrequently our essential humanitarian values are lost (Kertajaya et al., 2006).

\section{Sharia Marketing Principles}

\section{a. Sustainable Marketing Enterprise (SME)}

A marketing model in which the company can survive and succeed is not only at this time but also in the future. The company is experiencing phases as the human life phase, which should be able to sustain itself at critical times and changes in condition 
188 | Istiqomah, Richa Angkita Mulyawisdawati, Meriyati, THE IMPLEMENTATION OF SHARIA......

situation. If the company wants to live and succeed then the company's leader should be able to perform creative destruction actions before the crisis comes. A good company is a company that can bring its situation to life in a constantly changing market.

\section{b. Sharia Marketing Business Landscape}

Change is a thing that is going to happen. The power of change itself consists of five elements namely technological change, economic change, political change, socialcultural change, and the latter is the market change. The most major change is the technological change because the technological change will give a wider effect on all aspects that will also change. Technological developments can have considerable influence on sharia-based companies. In addition to supporting operational and standard technology services is also very instrumental in demonstrating the seriousness in implementing the principles of Sharia marketing. Because technology can provide convenience for consumers to get information and communicate.

\section{c. Sharia Marketing Strategy}

Segmentation is the art of identifying and taking advantage of emerging opportunities in the market. Targeting is a strategy to effectively allocate company resources because resources are limited. The strategy for capturing the position of the consumer or community is a strategy related to how to build trust, confidence, and competition for customers. Positioning is how a product is in the eyes of consumers who differentiate from competitors' products. In this case including brand image, the promised benefits, and competitive advantage.

\section{d. Sharia Marketing Tactic}

The creation of a product or product image is quite different from products that have been circulating to attract consumers. Marketing Mix is known as $4 \mathrm{p}$ with its elements: product, price, place, and promotion. As for the service company to be $7 p$ with additional process, people, and physical evidence. Selling is the delivery of goods or services from sellers to buyers with an agreed price voluntarily. 


\section{e. Sharia Marketing Value}

A brand is a name or symbol that distinguishes or identifies the goods or services of a merchant or a particular group. A good brand is a brand that has strong character and for the company or product that implements Sharia marketing or Sharia principles. To become a large and sustainable company, the company based on Sharia marketing must maintain and improve the services offered to maintain the satisfaction of its customers. In conducting company services, one must pay attention to attitudes, good talks, discussing the body, is sympathetic, gentle, polite, respectful, and affectionate.

\section{f. Sharia Marketing Scorecard}

Created A Balanced Value to Your Stakeholders (scorecard). The principle in Sharia marketing is creating value for its stakeholders. The three stakeholders of a company are people, customers, and, stakeholders because the trio plays a role in doing business (Kertajaya et al., 2006).

\section{h. Customer Satisfaction}

The satisfaction of consumers according to Kotler is a feeling of pleasure or disappointment felt by someone who comes from a comparison of his impressions on the performance or outcome of a product as his hopes. If the fact is more than what is expected, then the service can be said to be not quality. Conversely if reality is the same as expected, then service can be said to be satisfactory (Rambat Lupiyoadi, 2006).

According to Tjiptono (2007) Customer satisfaction is an after-sales evaluation of which the chosen alternative outcome at least give the same results or exceed the customer please, while the dissatisfaction arises if the results obtained do not meet customer expectations (Tjiptono \& Fandy, 1997). As customers will also feel the satisfaction if the products, services and services of Sharia banks are appropriate or beyond expectations (Kertajaya et al., 2006). 
190 | Istiqomah, Richa Angkita Mulyawisdawati, Meriyati, THE IMPLEMENTATION OF SHARIA......

\section{i. Factors affecting customer satisfaction}

There are five factors must be noticed by an enterprise to increase the customer satisfaction (Febriana, 2016), they are;

1) Product quality

Customers will be satisfied if the evaluation results indicate that the product, they are using is quality. Rational consumers will always expect the quality products in direct proportion to the sacrifices they make to obtain the product. So that the quality of good products will certainly be added value to the consumer's heart.

2) Service Quality

Service quality is the most important factor especially in the field of services. Customers will be satisfied if the service they get is appropriate or exceeds the expected. Customers who are happy to willingly give their perception to the service they get and will likely come back again to buy the same product.

3) Emotional

A feeling of pride will also affect customer satisfaction in using a particular product or brand because they gain the trust and admiration of others. Therefore, satisfaction is not only obtained because of the quality of the product but also from social value or pride (prestige) that makes the customer satisfied with the particular brand.

4) Price

The same quality products offered at a relatively cheap prices then will give higher value to the customers.

5) Cost

Customers do not need to spend an additional fee to obtain a product or service to get satisfaction on such products and services. Customer expectations can be built by past experiences, comments from friends or relatives, and information from marketers and rivals. Satisfied consumers will show their loyalty for longer and will certainly give good comments about the company. 
ISLAMIC BANKING: Jurnal Pemikiran dan Pengembangan Perbankan Syariah, Volume 6 Nomor 2 Edisi Februari 2021

\section{Research Methodology}

This research is field Research which is research directly into setting. The setting of the research is Muamalat Bank of Bantul Branch Office.

The research methodology is a qualitative method, Bogdan and Taylor define it as a research procedure that generates descriptive data of written or spoken words about the people and behaviors observe (Moleong, 2010). In this research the researcher collects the datas relating to the implementation of Sharia marketing in Muamalat Bank of Bantul Branch Office.

The subjects and objects in this study are the Muamalat Bank of Bantul Branch Office servant. The stakeholders used for the research object include the CEO of The BMI of Bantul Branch Office and the Manager Marketing.

Data obtained through the interview process, field notes, and documentation are then analyzed by organizing them into categories, defined into units, performed syntheses, and organized into patterns and then selected which are important and will be learned and drawn conclusions so that they are easily understood by oneself and others.

\section{Results and Discussion}

\section{The Implementation of Syariah Marketing Characteristic of Muamalat Bank of Bantul Branch Office}

The implementation of Sharia marketing characteristic in Muamalat Bank of Bantul Branch Office overall has been following the provisions of Syariah marketing, including;

a. Theistic (Rabbaniyyah)

One characteristic of Syariah marketing that is not owned by the conventional marketing is the religious nature (Diniyyah). The soul of a Shariah marketer believes strongly that the Islamic laws of Divinity are very fair so that a Shariah marketer will obey every marketing activity done. Start from conducting a marketing strategy, sorting through the market (Segmentation), then sorting out which market should be the focus 
(targeting), to establish the identity of the company that should be always embedded in the mind of the customer (positioning).

In its implementation, the marketers at the Muamalat Bank of Bantul Branch have had religious properties, it is reflected in the behavior of the marketers, at the time in the office or outside the office when they want to do a marketing strategy, in sorting and choosing a market that can be targeted or not to be targeted. A marketer is always sorting out the markets that do not come out of Islamic Sharia, should not contain elements Maghrib (Ghoror, RIBA, nor maisir, etc.). In setting prices and conducting promotions without cheating, fraud, or exaggeration with the intention that the customer is easily interested. ${ }^{1}$

As Allah has spoken at the Qur'an, Sura Al-Zalzalah: 7-8:

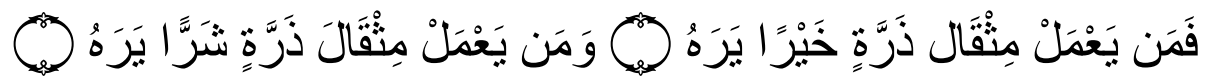

"Whosoever does a good for the atomic seed though, then he will see it and whosoever commits an evil by the atom, then he will see it anyway". (QS AlZalzalah: $7-8)$

b. Ethically (Akhlaqiyyah)

Sharia marketers should have a marketing concept that strongly puts on moral problems (morality, ethics) no matter any tribe, religion or race, distancing itself from the nature of lies or deception and deceit.

In increasing customer satisfaction in the Muamalat Bank Bantul Branch Office, the marketers never discriminate Muslim and Non-Muslim customers, customers outside the city or in the city. They always provide service as well as possible, polite and just without discriminate each other according to the SOP. ${ }^{2}$

As the prophet has revealed in a hadith:

"The Apostles are not like his brethren. Their shariah is many, but his religion (creed) is one (i.e. administering God) " (narrated Al-Bukhari, Abu Dawood, and Ahmad).

An example of a marketer's activity when dealing with a jammed financing is done by deliberation, if there is no decision or point of intersection, then it is brought to the

\footnotetext{
${ }^{1}$ Interview results to Mr. Fuad Uli Addien, RM. Consumer, 23 December 2019, at: 2:00 pm

${ }^{2}$ Interview results to Mr. Fuad Uli Addien, RM. Consumer, 23 December 2019, at: 2:00 pm

${ }^{3}$ Interview results to Mr. Fuad Uli Addien, RM. Consumer, 23 December 2019, at: 2:16 pm P-ISSN : 2460-9595

E-ISSN : $2686-5149$
} 
Religious Court. If there is a good ethics, then all can be communicated to the debtor. Before the auction occurred, marketers searched and finally made SP 1 to SP 3. If no longer can, then the debtor financing in the record is stuck. In the provision of fines of delays inserted into social funds, do not put into bank's income. ${ }^{3}$

\section{c. Realistic (Al-Waqiiyyah)}

A Shariah marketer is a professional marketer with a clean, neat, and understated appearance, whatever model or style of dress he wears. They always work professionally, not stiff, flexible in being and associating, and promoting religious values, purity, moral aspects, and honesty in all its marketing activities.

In practice, the marketers at the Muamalat Bank of Bantul Branch Office has implemented this character properly and correctly. Judging from the way they dress up is always neat and flexible, and always serve customers as well, polite, flexible in communicating and easy to associate or familiar with customers. In the case of any breach, SP 1 through SP 3 until discharge is applied. ${ }^{4}$ As the words of Prophet Muhammad SAW:

"Indeed, Allah has set his terms, and you shall not break. He has set up some mandatory things, do not you are violating. And he has deliberately suffered some things as a form of his love for you, do not you matter. " (Narrated by AlDaruquthni).

\section{d. Humanistic (Al-Insaniyyah)}

A marketer who has a humanistic nature, they always control themselves so as not to fall in the greed that always justify the various ways to get the profit they want.

In this aspect, the marketers at the Muamalat Bank of Bantul Branch Office always work honestly, never exaggerating anything in the promotion or explaining their products to the customers. They always convey the products of Muamalat Bank what it

\footnotetext{
${ }^{4}$ Interview results to Mr. Fuad Uli Addien, RM. Consumer and observation of researchers on 23 December 2019, at: 2:40 pm. 


\section{4 | Istiqomah, Richa Angkita Mulyawisdawati, Meriyati, THE IMPLEMENTATION OF SHARIA.......}

is, this can be seen from the way marketers serve and provide explanations about products to customers. $^{5}$

As well as the Prophet Muhammad SAW said, he ordered to establish Ukhuwah. The principle of this brotherhood is made the main principle of "... I testify that all the servants are brothers "characterize and the character of all men in all interactions in business, in competing healthily, and in partnering".

\section{The implementation of Syariah Marketing Principles in the Muamalat Bank of Bantul Branch Office ${ }^{6}$}

Based on the results of observation and interviews to one of the marketing staff, the principle of Sharia marketing implemented in Muamalat Bank of Bantul Branch Office has been conducted to the provisions contained in Syariah marketing, includes;

\section{1) Sharia Marketing Strategies}

Islamic marketing strategy should be able to identify and exploit emerging market opportunities, can effectively allocate the company's resources, able to determine the target market that will be shot, and build a trust, confidence, and competition for customers to distinguish from competitors' products.

In increasing customer satisfaction in the Bank Muamalat of Bantul Branch Office, there are several activities in the allocation of resources, utilization of existing business opportunities, Muamalat Bank provides facilities such as e-Chanel, mobile banking, internet banking, and smartphone-based facilities smartphone, priority services with several advantages including; Exclusive Flow at the airport, discount shopping and free transactions. Muamalat Bank always prioritize honesty, politely, and discipline to build customer trust and confidence.

As stated by Shafi'i Antonio, that Sharia has its own uniqueness. Sharia is not only comprehensive, but also universal. The comprehensive is that Islamic Shariah summarizes all aspects of life, both ritual (worship) and social (Muamalah). Worship is necessary to maintain the obedience and harmony of human relations with its creation.

5 The results of interviews to Mr. Fuad Uli Addien, RM. Consumer and observation of researchers on 23 December 2019, at: 3:00 pm.

${ }^{6}$ The results of interviews to Mr. Fuad Uli Addien, RM. Consumers and observations of researchers on 24 December 2019, at: 2:00 pm. 
The social aspect is revealed to be rules of the game or the rules of play in community life. While universal means that sharia can be applied in any time and place by every human being. This universality is especially evident in the social field which is not discriminate between Muslims and non-Muslims (Kertajaya et al., 2006).

\section{2) Sharia Marketing Tactic}

Sharia marketing tactics should create and combine different products with products that have been circulating and maximize sales activities by creating a win-win solution. In enhancing customer satisfaction, Muamalat Bank of Bantul Branch Office establish ATM infrastructure and branches that have long been a homework and all decisions are in the head office. Muamalat Bank is promoting a branch that has not existed in Yogyakarta for example in Kulonprogo and Gunung Kidul. To increase the number of customers, the bank is more to "pick up the ball" by a relationship Manager/marketing, marketing funding that serves specifically to find the Customer/Fund entry that until now became the ultimate soldier Muamalat Bank.

\section{3) Sharia Marketing Value}

Brand or good brand in sharia marketing is a must have strong character for the company, maintain and improve the service well to maintain the satisfaction of its customers. In the implementation of increasing customer satisfaction, Muamalat Bank of Bantul Branch does not have a convent parent, Muamalat Bank stand-alone without any rule of government. The Muamalat Bank Logo is a calligraphy with the basic colors of purple and green calligraphy symbolizing the characteristic of Muamalat Bank with its validity.

The products of Muamalat Bank are basically not much different from other bank's products. Muamalat Bank distinguishes its trademark by providing a Shar'i service and providing products that comply with sharia rules. Muamalat Bank always maintain the quality of its purity as the network is the first pure Sharia Bank in Indonesia, so that in 
196 | Istiqomah, Richa Angkita Mulyawisdawati, Meriyati, THE IMPLEMENTATION OF SHARIA......

operation always prioritize the Syari'ah value, will not be shaken by the practices that there are gaps ribawi in it.

\section{Conclusion}

Based on the results of research conducted by researchers at Muamalat Bank of Bantul Branch, data analysis and checking the validity of data obtained from the field, it can be concluded that both characteristics and principles of Sharia marketing has been implemented by Muamalat Bank of Bantul Branch in some aspects, including; (1) Theistic (Rabbaniyyah) that is applied in the form of basic views of leaders and employees about working as a worship. To draw closer to Allah SWT, the director and all employees always start their work by the morning prayer together, a routine tadarus once a week; (2) Ethical (Akhlaqiyyah) is implemented through regular training conducted by Muamalat Bank once a month, including knowledge review both general knowledge and religion to improve knowledge for employees; (3) Realistically (alWaqiiyyah) is implanted with a professional attitude to the customer, without discriminate the customer either in a social strata or in the case of confidence, especially in terms of financing; (4) Humanistic (al-Insaniyyah) by providing tolerance to customers who have difficulties in the refund of borrowed and holding a deliberation to get a mutual agreement. The principles of sharia marketing that has been implemented are; Sharia marketing strategy, Syariah marketing Tactic and Sharia marketing Value. 


\section{BIBLIOGRAPHY}

Abdillah, Pius dan Prasetya, Danu, (2005). Kamus Lengkap Bahasa Indonesia Masa Kini, Surabaya: Arloka.

Aisjah, S., \& Hadianto, A. E. (2013). Performance Based Islamic Performance Index (Study on the Bank Muamalat Indonesia and Bank Syariah Mandiri. Asia Pacific Management and Business Application. https://doi.org/10.21776/ub.apmba.2013.002.02.2

Arif, Nur Rianto Al, (20120. Dasar-Dasar Pemasaran Bank Syariah, Bandung: Alfabeta.

Arifa, Anif Ni'matin, (2015). Implementasi Syariah Marketing dalam Meningkatkan Kepuasan Nasabah pada Bank Syariah Mandiri KCP Ambarukmo Yogyakarta, Skripsi tidak diterbitkan, Yogyakarta, Fakultas Dakwah dan Komunikasi Universitas Islam Negeri Sunan Kalijaga Yogyakarta.

Boediono, (2001). Kamus Lengkap Bahasa Indonesia, Surabaya: Karya Agung.

Echols, John M. dan Shadhly, Hasan, (1992). Kamus Inggris-Indonesia, Jakarta: Gramedia.

Febriana, N. I. (2016). Analisis Kualitas Pelayanan Bank Terhadap Kepuasan Nasabah Pada Bank Muamalat Indonesia Kantor Cabang Pembantu Tulungagung. AnNisbah: Jurnal Ekonomi Syariah. https://doi.org/10.21274/an.2016.3.1.145-168

Kertajaya, Hermawan dan Sula, Muhammad Syakir, Syariah Marketing, (Bandung: PT Mizan Pustaka, 2006)

Kotler, Philip dan Keller, Kevin Lane, Manajemen Pemasaran, ed. 12, (Jakarta: Indeks, 2000)

Mighfari, Elsha Robbi, Implementasi Islamic Marketing ditinjau dari Perspektif Maqoshid Syariah, Skripsi tidak diterbitkan (Malang, Fakultas Ekonomi Universitas Islam Negeri Maulana Malik Ibrahim, 2018)

Moleong, L. J. (2010). Meode Penelitian Kualitatif. Landasan Teori. https://doi.org/10.1017/CBO9781107415324.004

Mu'allim, A. (2003). Persepsi Masyarakat terhadap Lembaga Keuangan Syariah. AlMawarid. https://doi.org/10.20885/almawarid.vol10.art2

Nofinawati, N. (2016). PERKEMBANGAN PERBANKAN SYARIAH DI INDONESIA. JURIS (Jurnal Ilmiah Syariah). https://doi.org/10.31958/juris.v14i2.305

OJK. (2019). Statistik Perbankan Syariah September 2019. Otoritas Jasa Keuangan. https://doi.org/10.1017/CBO9781107415324.004 
198 | Istiqomah, Richa Angkita Mulyawisdawati, Meriyati, THE IMPLEMENTATION OF SHARIA......

Poerwadarminta, (2011). Kamus Bahasa Indonesia, Jakarta: PT. Balai Pustaka.

Rambat Lupiyoadi, H. (2006). Manajemen Pemasaran Jasa. Salemba Empat. Jakarta.

Sari, Bellina Reggita, (2018). Implementasi Syariah Marketing Dalam Meningkatkan Premi di PT Asuransi Takaful Keluarga Surabaya, Skripsi tidak diterbitkan, (Surabaya, Fakultas Ekonomi dan Bisnis Islam Universitas Islam Negeri Sunan Ampel Surabaya, 2018

Setyono, Langgeng, Kusumawati, Andriani, Mawardi, (2015). The Effect of Islamic Marketing and Corporate Image on Customer Satisfaction and Customer Loyalty, Jurnal Administrasi Bisnis Vol. 27, No. 1, Oktober 2015

Tjiptono, \& Fandy. (1997). Strategi Pemasaran, edisi kedua. Yogyakarta: Andi Ofset.

http://bank muamalat.co.id/profil-penghargaan-bank-muamalat (accessed December 20, 2019, at: 9:22 PM)

http://bankmuamalat.co.id/profil-bank-muamalat (retrieved 20 december 2019 at 5:19 PM)

https://keuangan.kontan.co.id/news closed on Sunday, April 5, 2020 at 1:47 PM

Interview result of Mr. Fuad Uli Addien, RM. Consumer, 23 December 2019,: 2:003:00 PM and 24 December 2019, at 2:00-3:00 PM 